\title{
Efektifitas Media Permainan Flashcard Dalam Meningkatkan Pengetahuan Kesehatan Reproduksi AnakUsia Prasekolah
}

\author{
${ }^{1}$ Fathimah Kelrey ${ }^{*},{ }^{2}$ Rita Kombong,${ }^{3}$ Tri N Hatala \\ ${ }^{1,2,3}$ Akademi Keperawatan Rumkit Tk III Dr. J. A. Latumeten \\ *Email : Fath.kelrey@gmail.com
}

\section{Kata kunci : \\ Flashcard, Pendidikan \\ Kesehatan, \\ Pengetahuan, \\ Kesehatan Reproduksi \\ Keywords : \\ Flashcard, Health \\ Education, \\ Knowledge, \\ Reproductive Health}

Info Artikel :

Tanggal dikirim :

17 September 2021

Tanggal direvisi :

12 Oktober 2021

Tanggal diterima :

3 November 2021

DOI Artikel :

10.33862/citradelima.

v5i2.239

Halaman: $56-60$

\begin{abstract}
Abstrak
Pelaksanaan media flashcard sebagai media pembelajaran kesehatan reproduksi bagi anak usia pra-sekolah masih sangat jarang diterapkan oleh perawat di lingkup komunitas untuk memberikanpendidikan kesehatan. Tujuan penelitian untuk meningkatkan pengetahuan anak usia pra-sekolah tentang kesehatan reproduksi melalui flashcard. Metode Desian penelitian ini adalah eksperimental analitik menggunakan pre eksperiment dengan pendekatan pretest-postest design tanpa adanya kelompok kontrol. Teknik sampling yang digunakan adalah purposif sampling dengan jumlah sampel 30 responden. Kemudian dilakukan uji statistic dependen sample t-test (paired t test dengan $\alpha$ (taraf kesalahan) sebesar 5\%. Hasil dalam penelitian ini setelah dilakukan Uji Paired T-Test menunjuka niali p-value 0.000 atau $<0.05$ yang berarti ada perbedaan nilai pre dan post test tingkat pengetahuan setelah dilakukan perlakuan. Kesimpulan adanya peningkatan tingkat pengetahuan setelah dialakukan perlakuan pendidikan kesehatan kepada anak usia prasekolah dengan menggunakan media flashcard. Saran, media flashcard dapat digunakan sebagai media pembelajaran pada anak usia dini.
\end{abstract}

\section{The Effectiveness of Flashcard Game Media in Increasing Preschool Age Reproductive Health Knowledge}

\begin{abstract}
The implementation of flashcard media as a reproductive health learning media for preschool children is still very rarely applied by nurses in the community to provide health education. The aim of this research is to increase the knowledge of pre-school age children about reproductive health through flashcards. Method The design of this research is experimental analytic using pre experiment with pretest-posttest design approach without any control group. The sampling technique used is purposive sampling with a sample of 30 respondents. Then a statistical test of the dependent sample t-test (paired t test with (error level)) of 5\% was carried out. The results, the results of the Paired T-Test showed a p-value of 0.000 or $<0.05$, which means there is a difference in the value of pre and post test levels knowledge after treatment. In conclusion, there is an increase in the level of knowledge after the treatment of health education for preschool age children using flashcard media Suggestions, flashcard media can be used as a learning medium in early childhood.
\end{abstract}




\section{PENDAHULUAN}

Kesehatan Reproduksi adalah kondisi sehat secara menyeluruh meliputi fisik, mental dan kehidupan sosial yang berkaitan dengan alat, fungsi serta proses reproduksi sehingga kesehatanreproduksi tidak terbatas pada kondisi yang bebas dari penyakit melainkan seseorang dapat memiliki kehidupan seksual yang aman dan memuaskan sebelum dan sesudah menikah (Prijatni \& Rahayu, 2016).

Kesehatan reproduksi pada anak usia pra-sekolah yaitu pengenalan nama dan fungsi organ reproduksi mereka. Salah satu permasalahan Kesehatan reproduksi yang dihadapi anak usia pra-sekolah adalah permasalahan kekerasan atau pelecehan sexual. Kasus kekerasan seksual pada anak di Indonesia mengalami peningkatan dalam 5 tahun terakhir, berdasarkan data dari Lembaga Perlindungan Saksi dan Korban (LPSK) mencatat ada peningkatan kasus kekerasan seksual pada anak yang terjadi sejak 2016 sejumlah 25 kasus meningkat pada 2017 menjadi 81kasus dan puncaknya pada 2018 menjadi 206 kasus. Angka tersebut diprediksikan terus bertambah setiap tahunnya (Matius, 2019).

Peningkatan jumlah kekerasan seksual pada anak di tahun 2020 sebelum pandemi di bulan Januari-Febuari 2020 berjumlah 1.524 dan meningkat menjadi 2.367 anak korban pada masa pandemi Covid-19 di awal bulan Maret 2020 (Fakhrizal, 2020). Persentasi kekerasan sexual dan fisik pada anak di Kota Ambon tahun 2020 diatas $50 \%$ berdasarkan data Pusat Pelayanan Terpadu Pemberdayaan Perempuan dan Anak (P2PT2A) ditahun 2018 sebanyak 30 kasus dan meningkat menjadi 85 kasus di tahun 2019 dan di tahun 2020 triwulan pertama tercatat sebanyak 27 kasus kekerasan pada anak (Rulin, 2020).

Anak merupakan kelompok yang rentan atau beresiko terhadap masalah kesehatan reproduksi termasuk anak usia pra-sekolah karena anak selalu diposisikan sebagai sosok lemah atau yang tidak berdaya dan memiliki ketergantungan yang tinggi dengan orang-orang dewasa di sekitarnya. Hal inilah yang membuat anak tidak berdaya saat diancam untuk tidak memberitahukan apa yang dialaminya (Noviana, 2015). Upaya yang sudahdilakukan sebagai langkah pencegahan dan penanganan terhadap masalah Kesehatan reproduksi pada anak melalui program pemberdayaan perempuan dan anak (P2PT2A) dan juga melalui Puskesmas maupun Rumah sakit, walaupun sudah ada program pemerintah terkait pencegahan dan penanggulangan kekerasan terhadap anak baik kekerasan fisik, sexual, psikologi maupun sosial namun program tersebut belum secara optimal merata di setiap daerah di kawasan Indonesia baik dalam pelaksanaan maupun hasillnya di Maluku tercatat angka keoptimalan pencegahan dan penanggulangan yang dilakukan di Puskesmas sebesar $79 \%$ berada dibawah daerah lain yang angka keoptimalannya mencapai 123-284 \% (Infodatin, 2018).

Beberapa faktor yang berpengaruh terhadap perilaku seksual dan program pendidikan seksual antara lain nilai-nilai yang berlaku di keluarga, hubungan orang tua dan masih kurangnya informasi dan pengetahuan tentang seks (Lee YM, Florez E, Tariman J, McCarter S, Riesche L, 2015). Salah satu upaya pencegahan dini masalah Kesehatan reproduksi pada anak khususnya anak usia pra-sekolah yaitu meningkatkan pengetahuan melalui media flashcard (Sage, K., Rausch, J., Quirk, A., \& Halladay, L, 2016).

Penelitian ini bertujuan menganalisis keefektifan media permainan flashcard dalam meningkatkan pengetahuan anak usia prasekolah dan juga meningkatkan / menimbulkan motivasi siswa dalam mempelajari sesuatu dan meningkatkan keaktifan / keterlibatan siswa dalam kegiatan pembelajaran. Kebaruan dalam penelitian ini adalah pelaksanaan media flashcard sebagai media pembelajaran kesehatan reproduksi bagi anak usia pra-sekolah masih sangat jarang diterapkan oleh perawat di lingkup komunitas di sekolah untuk memberikanpendidikan kesehatan. Oleh karena itu peneliti merasa perlu meneliti tentang efektifitas media flashcard untuk meningkatkan pengetahuan anak usia pra-sekolah tentang kesehatan reproduksi.

\section{METODE}

Jenis penelitian yang digunakan adalah penelitian kuantitatif. Desain penelitian ini adalah eksperimental analitik menggunakan Pre-eksperiment dengan pendekatan Pretest-Posttest Design tanpa adanya kelompok kontrol (Sugiono, 2013). Penelitian dilaksanakan di RA IT Yaa Bunayya Hidayatullah Ambon pada tanggal 18 Agustus sampai dengan 10 Agustus 2021. Teknik pengumpulan data yang dilakukan peneliti yaitu menentukan responden dengan menggunakan teknik purposive sampling sesuai dengan kriteria inklusi yaitu anak usia prasekolah usia 5-6 tahun, anak yang hadir saat penelitian, dan mendaptkan persetuuan dari orangtua dengan jumlah sampel 30 responden. Analisis data yang digunakan adalah Analisis bivariate digunakan untuk mengetahui pengaruh media pendidikan flashcard terhadap tingkat pengetahuan kesehatan reproduksi anak usiaprasekolah dengan uji statistic dependen sample t-test (paired t test

http://jurnalilmiah.stikescitradelima.ac.id/index.php/JI Vol.5 No.2 Januari 2022 
dengan $\alpha$ (tarafkesalahan) sebesar 5\%. Kuisioner yang digunakan dalam penelitian ini adalah kuisioner kesehatan reproduksi yang telah dilakukan uji validitas dan reliabelitas dengan nilai signifikan $\mathrm{p}<0,005$. Sedangkan untuk reliabelitas jika $r$ hasil ( $\mathrm{r}$ alpha) > konstanta(0,6). Dari Hasil uji validitas yang dilakukan oleh 10 orang sampel didapatkan 0,01 sedangkan untuk uji realibitas 0,928. Penelitian ini mendapatkan Etichal Clearence dari Komisi Etik Penelitian denganNo.5.16/KEPK/SSG/VIII/2021.

\section{HASIL DAN PEMBAHASAN}

Hasil

Tabel 1. Umur Anak Usia PraSekolah

\begin{tabular}{llll}
\hline No. & Usia & N & F \\
\hline 1. & 5 th & 13 & $43,3 \%$ \\
2. & 6 th & 17 & $56,7 \%$ \\
\hline Total & & 30 & $100 \%$ \\
\hline
\end{tabular}

Berdasarkan tabel 1 hasil analisis univariat data distribusi frekuensi menunjukan usia responden paling banyak berada pada usia 6 tahun yaitu 17 responden $(56,7 \%)$ dan paling sedikit 5 tahun yaitu 13 responden $(43,3 \%)$.

Tabel 2. Jenis Kelamin

\begin{tabular}{llll}
\hline No. & JK & N & F \\
\hline 1. & L & 13 & $43,3 \%$ \\
2. & $\mathrm{P}$ & 17 & $56,7 \%$ \\
\hline Total & & 30 & $100 \%$ \\
\hline
\end{tabular}

Berdasarkan tabel 2 hasil analisis univariat data distribusi frekuensi menunjukan jumlah jenis kelamin sebanyak 30 responden, paling banyak perempuan 17 responden $(56,7 \%)$ dan paling sedikit laki-laki 13 responden $(43,3 \%)$.

Tabel 3. Analisis Tingkat Pengetahuan Pre Dan Post Tes Setelah Dan Sebelum Dilakukan Perlakuan

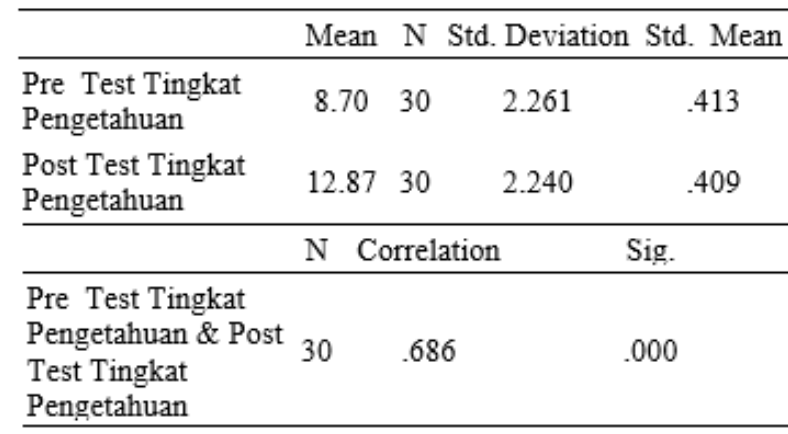

Berdasarkan tabel 3 diatas menunjukan bahwa terdapat perbedaan pengetahuan yang signifikan antara sebelum dan setelah diberikan edukasi melalui flaschard dengan $\mathrm{p}$ value $0,0000(\alpha<0,05)$. Nilai pengetahuan setelah diberikan edukasi melalui flaschar lebih tinggi dibandingkan sebelum diberikan edukasi flaschard.
PEMBAHASAN

\section{Pendidikan Kesehatan Reproduksi Anaka Usia Prasekolah}

Kesehatan reproduksi adalah kondisi sehat secara menyeluruh mencakup fisik, mental dan kehidupan sosial yang berkaitan dengan alat, fungsi serta proses reproduksi sehingga kesehatan reproduksi tidak terbatas pada kondisi yang bebas dari penyakit melainkan bagaimana seseorang dapat memiliki kehidupan seksual yang aman dan memuaskan sebelum dan sesudah menikah (Prijatni, 2016).

Menurut United Nations Educational, Scientific And Cultural Organization (UNESCO) pendidikan kesehatan reproduksi merupakan sebuah pendidikan yang dikembangkan dengan pendekatan yang disesuakani dengan usia, peka budaya dan menyeluruh yang mencakup program yang memuat informasi ilmiah akurat, realistis dan tidak bersifat menghakimi. Pendidikan kesehatan reproduksi akan membantu anak/remaja untuk memiliki informasi yang akurat menyangkut tubuh serta aspek reproduksi dan seksual secara akurat serta memiliki nilai-nilai positif dalam memandang tubuh serta aspek reproduksi dan seksual dan juga memiliki keterampilan untuk melindungi diri dari resiko- resiko reproduksi dan seksual termasuk kemampuan memperjuangkan hak-hak remaja untuk sehat (Handayani, 2017).

Menurut penelitian yang dilakukan oleh Dewiani 2019 mengatakan bahwa dengan adanya pendidikan ini anak-anak dapat mencegahan terjadinya kekerasan dan pelecehan seksual serta menjaga kesehatan tubuhnya secara baik, dan sebagai keberlanjutan pengabdian telah dibentuk wadah Bimbingan dan Konsling Seks Dini dan Kesehatan Reproduksi Anak di masing-masing sekolah. Pendidikan kesehatan bisa dimulai dari orangtua di rumah bagaimana orangtua mempunyai komitmen dalam mengasuh anak seperti penelitian yang dilakukan Hatala (2019) mengatakan bahwa komitmen dari seorang ayah yang mempersepsikan dirinya bahwa dia mampu dan mempunyai tanggung jawab dalam mengasuh anaknya hingga dewasa nanti. Oleh karena itu perlunya pemberian pendidikan kesehatan reproduksi pada anak usia prasekolah untuk bekal anaknya nanti jika dewasa.

\section{Pemberian Flashcard sebagai media pembelajaran}

Flashcard adalah kartu kecil yang berisi gambar, teks, atau tanda simbol yang mengingatkan atau mengarahkan siswa kepada sesuatu yang berhubungan dengan gambar.Flashcard biasanya berukuran 8 X 12 $\mathrm{cm}$ atau dapat disesuaikan dengan besar kecilnya kelas

http://jurnalilmiah.stikescitradelima.ac.id/index.php/JI Vol.5 No.2 Januari 2022 
yang dihadapi. Flashcard adalah media pembelajaran dalam bentuk kartu bergambar yang berukuran $25 \times 30$. Gambar-gambarnya dibuat dengan tangan, foto atau memanfaatkan gambar/foto yang sudah ada ditempelkan pada lembaran-lembaran flashcard (Azhar , 2015).

Kelebihan media flashcard sebagai media pembelajaran memiliki kelebihan praktis, menarik dan mudahdiingat dan membuktikan bahwa penggunaan kartu media flashcard dapat meningkatkan kemampuan mengenali simbol angka 1 hingga 5 (Satriana, 2013). Efektifitas flashcard dalam pemberian materi pendidikan yaitu didukung oleh peran pendidik dalam menanggapi atau memberikan respon umpan balik pada secara langsung pada siswa (Cazzel, 2016). Hasil penelitian menunjukan flashcard tradisional (berbahan kertas) juga dapat meningkatkan pembelajaran kosakata padaanak-anak dan khususnya anak usia prasekolah (Chen, 2019).

Menurut penelitian yang dilakukan oleh Firdaus (2019) yaitu kartu edukasi bergambar atau flashcard maupun kartu edukasi tulisan memeiliki keefektifan yang dapat digunakan sebagai media stimulasi bahasa anak usia prasekolah dalam meningkatkan pengetahuannya. Oleh karena itu perlunya pendidikan kesehatan untuk menambah kelimuan kepada anak usia prasekolah. Sesuai dengan penelitian yang dilakukan oleh Kelrey (2020) bahwa adanya pengaruh pendidikan kesehatan dala menngkatkan pengetahuan kesehatan reproduksi. Jadi dengan adanya media flashcard dapat membantu anak usia prasekolah dalam meningkatkan pengetahuan anak tentang kesehatan reproduksi.

\section{SIMPULAN}

Berdasarkan dari hasil penelitian dapat disimpulkan bahwa ada peningkatan tingkat pengetahuan setelah dialakukan perlakuan pendidikan kesehatan kepada anak usia prasekolah dengan menggunakan media flashcard.

\section{DAFTAR PUSTAKA}

Azhar Arsyad, (2015). Media Pembelajaran, Jakarta: Rajawali Press.

Cazzell, S., Browarnik, B., Skinner, A., Skinner, C., Cihak, D., Ciancio, D., ... Forbes, B. (2016). Extending Research on a Computer-Based Flashcard Reading Intervention to Postsecondary Students With Intellectual Disabilities. School Psychology Forum, 10(2), 191- 206.Retrieved from http://ezproxy.montclair.edu:2048/login?url=ht tp://search.ebscohost.com/login.aspx?direct=tr $\mathrm{ue} \& \mathrm{db}=\mathrm{ehh} \& \mathrm{AN}=119790526 \&$ site $=$ ehostlive $\&$ scope $=$ sit
Chen, R. W., \& Chan, K. K. (2019). Using Augmented Reality Flashcards to Learn Vocabularyin Early Childhood Education. https://doi.org/10.1177/0735633119854028

Dewiani, K., Purnama, Y., \& Yusanti, L. (2019). Pendidikan Seks Dini Dan Kesehatan Reproduksi Anak Untuk Siswa Sekolah Dasar. Dharma Raflesia: Jurnal Ilmiah Pengembangan Dan Penerapan Ipteks, 17(2).

Fakhrizal Fakhri (2020). Angka Kekerasan Anak Sebelum \& Sesudah Pandemi Covid-19 https://nasional.okezone.com/read/2020/0 7/23/337/2250692/ini-angka-kekerasananak- sebelum-sesudah-pandemi-covid19. Diaskes 24 Oktober 2020

Firdaus, N. Khansa (2019). Perbedaan Efektifitas Stimulasi Bahasa Metode Glenn Doman Melalui Flashcard Bergambar dan Flashcard Tulisan Terhadap Perkembangan Bahasa Anak Usia Prasekolah di Kelompok B TK Al-Jihad Kota Malang. E-ISSN : 25496581DOI:10.21776/ub.JOIM.2019.003.03 .4

Handayani, S. W. (2017). Pelaksanaan Program Pendidikan Kesehatan Reproduksi Dan Seksualitas Pada Ibu Dan Anak Didik Tk Labschool Unnes Dengan Menggunakan Boneka Gender. In Seminar Nasional Kesehatan Reproduksi Menuju Generasi Emas (Vol. 1, No. 1, pp. 82-88).

Hatala,N.Tri. (2019). Father's Involvement In Parenting Of Pre-School Batumerah Village Working Area Of The Rijali Puskesmas Ambon City. Third International Seminar on Global Health (3rdISGH)Technology Transformation in Healthcare for a Better LifeISGH $3 \mid$ Vol 3. No. 1 | Oktober 2019| ISSN : 2715-1948

Infodatin (2018). Kekerasan terhadap anak dan Remaja:Jakarta

Kelrey, Fatimah (2020). Pengaruh Pendididkan Kesehatan Dalam Meningkatkan Pengetahuan Kesehatan Reproduksi Anak Disabilitas Intelektual. Moluccas Health Journal Issn 2686-1828 Vol. 2 No. 2

Lee YM, Florez E, Tariman J, McCarter S, Riesche L. Factors related to sexual behaviors and sexual education programs for AsianAmerican adolescents. Appl Nurs Res [Internet]. 2015;28(3):222-8. Available from: http://dx.doi.org/10.1016/j.apnr.2015.04.0 15

Matius Alfons (2019) Kasus Kekerasan Seksual pada Anak Meningkat Tiap Tahun. Jakarta. Sumber: https://news.detik.com/berita/d4637744/lpsk-kasus-kekerasan-seksual-

http://jurnalilmiah.stikescitradelima.ac.id/index.php/JI Vol.5 No.2 Januari 2022 
pada-anak- meningkat-tiap-tahun. Diaskes 16 Oktober 2020

Noviana (2015). Kekerasan Seksual Terhadap Anak: Dampak Dan Penanganannya Child Sexual Abuse: Impact And Hendling

Prijatni, I \& Rahayu, S (2016). Modul Bahan ajar cetak kebidanaan:kesehatan reproduksi dankeluarga berencana. Cetakan 1: Jakarta

Rulin Purmiasah (2020). Triwulan $1 / 2020$ ada 27 kasus kekerasan anak di Ambon. https://www.malukuterkini.com/2020/07/3 0/triwulan-i-2020-ada-27-kasus-

kekerasan-anak-di- ambon/

Sage, K., Rausch, J., Quirk, A., \& Halladay, L. (2016). Pacing, Pixels, and Paper: Flexibility in Learning Words from Flashcards, 15, 431-456. Retrieved from http://www.informingscience.org/Publicat ions/3549

Satriana, A., Yunus, M., \& Fatmawati, F. (2013). Meningkatkan Kemampuan Mengenal Lambang Bilangan 1 Sampai 5 Melalui Media Flash Card Bagi Siswa Tunagrahita Sedang. Jurnal Penelitian Pendidikan Khusus, 2(2) 